MichU

CenRED

$\mathrm{R}$

非 28

\title{
Budget Policy and Economic Stability in Postwar Japan
}

\author{
by \\ WAYNE W. SNYDER \\ and \\ Tsutomu Tanaka
}
CRED Reprints
(New Series)
No. 28

Center for Research on Economic Development

University of Michigan

Ann Arbor, Michigan 48108 


\section{Center for Research on Economic Development CRED Reprints}

*No. 1. "Nigerian Government Spending on Agricultural Development: 1962/3-1966/7" by Jerome C. Wells. (The Nigerian Journal of Economic and Social Studies, November 1967, pp. 246-275)

No. 2. "Major Issues of Wage Policy in Africa" by Elliot J. Berg. (Industrial Relations in Economic Development edited by Arthur M. Ross, Macmillan, 1965, pp. 185-208)

*No. 3. "The Myth of the Amorphous Peasantry: A Northern Nigerian Case Study" by Polly Hill (Mrs. M. E. Humphreys). (The Nigerian Journal of Economic and Social Studies, July 1968, pp. 239-260)

*No. 4. "Urban Real Wages and the Nigerian Trade Union Movement, 1939-60: A Comment" by Elliot J. Berg. (Economic Development and Cultural Change, July 1969, pp. 604-617)

*No. 5. "Turkish Economic Development: The First Five Year Plan, 1963-67" by Wayne W. Snyder. (The Journal of Development Studies, October 1969, pp. 58-71)

*No. 6. "Hidden Trade in Hausaland" by Polly Hill, (MAN, Vol. 4, No. 3, September 1969, pp. 392-409)

*No. 7. "A Comment on Peter Kilby: Industrial Relations and Wage Determination" by John F. Weeks. (The Journal of Developing Areas, Vol. 3, No. 1, pp. 7-17)

*No. 8. "Measuring the Effects of Belgian Budget Policies: 1955-65" by Wayne W. Snyder. (Cahiers Economiques de Bruxelles, No. 44,1969 , pp. 527-548)

No. 9. "The Long Term Economic Development of Germany" by Wolfgang F. Stolper. Review Article of Walter G. Hoffmann, Das Wachstum der deutschen Wirtschaft, (Weltwirtschaftliches Archiv, Vol. 103, No. 2, 1969, pp. 57-61)

*No. 10. "International Financial Issues in Foreign Economic Assistance to the Less Developed Countries" by Robert M. Stern. (Economic Development and Structural Change edited by Ian G. Smith, Edinburgh University Press, 1969, pp. 47-70)

No. 11. "Money in a Developing Economy: A Reappraisal" by Wayne W. Snyder. (The Review of Economics and Statistics, Vol. LII, No. 1, February 1970, pp. 54-61)

*No. 12. "An Econometric Model of Development: Comment" by Peter Eckstein. (The American Economic Review, Vol. LX, No. 1, March 1970, pp. 227-235)

*No. 13. "Who Destabilizes Primary Product Prices?" by Richard C. Porter. (Indian Economic Journal, Vol. XVI, No. 4, April-June 1969, pp. 389-413)

*No. 14. "Two Types of Planning" by Wolfgang F. Stolper. (Schweizerische Zeitschrift für Volkswirtschaft und Statistik, Vol. 106, No. 1, 1970, pp. 45-58) 


\section{BUDGET POLICY AND ECONOMIC STABILITY IN POSTWAR JAPAN*}

\section{By Wayne SNyder ANd TSUTOMU TANAKA ${ }^{1}$}

THE "MIRACLE" of postwar Japanese growth is widely acknowledged, and a substantial literature now exists which attempts to interpret and explain the main features of this unique phenomenon. ${ }^{2}$ Our purpose is to compliment the existing studies by measuring the effects of various types of budget changes and evaluating their impact on the achievement of economic stability and balanced growth during the sixteen-year period from 1952 through $1967 . .^{3}$ The basic methods and framework of analysis are those developed by Bent Hansen [3] for a recent OECD survey which gives the institutional background to budgetary action and an analysis of the nature and effects of fiscal policy for each of seven member countries: Belgium, France, Germany, Italy, Sweden, the United Kingdom, and the United States. Here, we shall supplement the Hansen study by providing a similar analysis for another major country, Japan.

Economic stability is viewed from two different perspectives: the combined impact of all government budgets on short-term fluctuations in demand and their impact on the long-term achievement of full utilization of Japan's potential output. In addition, disaggregated budget impacts are examined for each government sector (e.g., central government, local government, social security, public enterprise investment), and discretionary changes are distinguished from automatic budget responses where possible. Section 1 describes briefly the structure and some of the main changes in public finance in Japan since 1952; Section 2 explains the methodology used to estimate the budget impact and gives the data for the effects of the various budget changes which are the basis for the subsequent analysis; Section 3 analyzes the impact of budget changes in relation to short-term stability, with a discussion of the automatic responses of the tax system; Section 4 assesses the degree to which the total budget enhanced the achievement of the full use of Japan's economic potential. The conclusion, Section 5, compares Japan's postwar budget experience with seven other OECD countries. Data used to calculate some of the relationships are given in the Appendix.

* Manuscript received July 29, 1970; revised April 19, 1971.

1 Our debt to Bent Hansen is great, as will become evident, and we wish to thank him warmly for developing the framework of analysis which is used in this study. We also wish to thank an anonymous referee for several suggestions which were used to improve this version, Bruce Snapp for aid in making many calculations, and Janet Eckstein for her editorial assistance.

2 For a concise, well written discussion of both the pre- and postwar periods, see Madison [9].

3 At least one other paper [5] deals with the same problem and employs a similar approach, although the period covered ends at 1960. Several recent (1970) issues of the Economic Planning Agency's journal [16] also contain studies about the government sector. 


\section{THE SIZE AND STRUCTURE OF THE PUBLIC SECTOR}

The public sector in Japan is smaller than in Western Europe and the United States. The sum of central and local government current expenditures for goods and services plus social security benefits and other transfers to households plus general government investment plus government enterprise and public corporation investment in fixed capital formation and stocks amounted to 20 per cent of GNP in 1951 (see Appendix, Tables A1-A4). During the following sixteen years it rose to 25 per cent, with the largest increases occurring in government enterprise and public corporation investment and social security benefits, but the comparable increases in the major Western countries were even larger (total public expenditures now average about 30 per cent of GNP but rise to a high of 40 per cent in Sweden). ${ }^{4}$ Total gross tax revenues (including social security contributions) were also relatively small in 1951 (21 per cent of GNP), and, contrary to the experience in other countries, they declined to a smaller proportion of GNP by the end of the period (19 per cent). Most of the decline occurred in the central government sector, where both direct taxes on households and indirect taxes declined as a percentage of GNP (see Section 3 for a general discussion of discretionary and automatic changes of the tax system).

The governmental system of public finance is extraordinarily complex; the central government includes a number of important "Special Accounts," and there is an interlocking arrangement of transfers and shared taxes with the local government sector. Nevertheless, if current and investment expenditures for goods and services are taken as the measure of comparison, in 1967 the local government sector was larger ( 8 per cent of GNP) than the central government sector (6 per cent of GNP). This too is an almost unique phenomenon: for most Western countries (except Germany) the reverse relationship is usual. As in the case among the other developed nations, the social security sector has grown the fastest; benefits increased from 1.6 to 3.5 per cent of GNP between 1951 and 1961. This is still a low percentage by European standards (typically near 10 per cent of GNP), but it is comparable with the United States, which like Japan relies more on privately financed social welfare plans than on public ones. Investments in fixed capital by government enterprises and public corporations was another area which increased its relative importance, growing from 1.7 to 3.8 per cent of GNP during the sixteen years.

\section{MEASURING THE IMPACT OF BUDGET CHANGES}

In order to evaluate the effect of budget policies on economic stability and growth, it is first necessary to estimate their impact on domestic demand. In this section we use the definition and methods developed by Hansen to estimate the budget effect; ${ }^{5}$ these are based, in turn, on the earlier contribution of Brown [1], Hansen [2], Lindbeck [7], and Musgrave [10]. Although the Hansen model

\footnotetext{
${ }^{4}$ For more comparative data about the other countries, see Hansen [3, (Chapter 2)].

5 For a complete description of the methods used to measure budgetary effects, see Hansen [3, (Chapter 1)].
} 
is small compared with the large econometric models which have been developed for some countries, including Japan, ${ }^{6}$ it is adequate to measure the relative importance of various types of budget changes. Although quarterly data exist for Japan, they are not sufficiently detailed to permit the desired degree of disaggregated budgetary analysis. Hence only year-to-year changes are used-as Hansen did also, in order to maintain comparability among all seven countries -and these are no lags. ${ }^{7}$ The model assumes that private investment and exports are exogenously determined. The model uses multipliers of various magnitudes to determine the impact of different kinds of budget changes, after allowing for leakages due to the estimated marginal propensities for consumption, imports, and direct and indirect taxes. Government expenditures distinguish between volume and price changes, the latter necessitated by the differentiation of direct from indirect taxes.

The Hansen methodology for measuring the combined impact on domestic demand of both automatic and discretionary effects of budget changes includes the direct impact brought about by the initial budget change as well as the subsequent indirect or "multiplier" effect. ${ }^{8}$ Hansen's formula for the total of all the direct and indirect effects is based on a truncated version of his model which allows for all changes in revenue which are not credit transactions and for all purchases of goods and services:

$$
\begin{aligned}
\text { Total Effect }= & \frac{1}{1-\alpha(1-\mu)}\left[(d g+d s)+\alpha(1-\mu)\left(g d p_{g}+s d p_{s}\right)\right. \\
& \left.-(1-\mu) d T_{i}-\alpha(1-\mu) d T_{d}\right]
\end{aligned}
$$

where $\alpha$ is the marginal propensity to consume; $\mu$ is the marginal propensity to import with respect to GNP; $d g$ and $d s$ are annual changes in the volume of goods and services (respectively) purchased by government; $g d p_{g}$ and $s d p_{s}$ are changes in the value of goods and services due to price or wage changes; $d T_{i}$ and $d T_{d}$ are annual changes in indirect and direct personal taxes.

The Hansen model also permits estimating, separately, the discretionary and automatic effects of budget changes. An explicit expression for the automatic effects of tax changes can be derived from the Hansen model, but as the total effects of budget changes are the sum of automatic and discretionary changes, it is easier to define them simply as the difference between total and discretionary effects. The formula for the latter is the following:

${ }^{6}$ For one of the several econometric models of the Japanese economy, see Tatemoto, Uchida, and Watanabe [11].

7 A review of several big models suggests that $3 / 4$ or more of the budget effect generally occurs during the first year, hence the absence of explicit lags is not critical; see Hansen [3, (20-22)].

8 An "accelerator" effect should be included too, but (as will be explained later) the model assumes that all changes in private investment are exogenously determined; hence the measure of the budgetary impact is limited in this respect as well as by the other factors described further on. 


$$
\begin{aligned}
\text { Discretionary effect }= & \frac{1}{1+t_{i}-\alpha(1-\mu)\left(1-t_{d}\right)}\left[(d g+d s)\left(1+t_{i}\right)\right. \\
& \left.-c d t_{i}(1-\mu)-y d t_{d}(1-\mu) \alpha\right]
\end{aligned}
$$

where $t_{i}$ and $t_{d}$ are the marginal rate of indirect and direct taxes on households, respectively, and $c d t_{i}$ and $y d t_{d}$ are discretionary changes in indirect and direct taxes, respectively. Equation (2) counts all changes in the volume of government purchases of goods and services as discretionary, whereas in reality some expenditures are tied to legislated norms and programs (e.g., social security benefits). On the other hand, all budget effects from changes in prices and wages paid by the government are considered to be automatic, although the government does have control over some prices (e.g., goods and services produced by government enterprises and public corporations, and commodity price support programs), and over when and by how much government wages are increased. But because the Japanese government is not highly centralized in its authority to fix prices permanently, eventually the salaries and prices it pays must adjust to those in the rest of the economy; hence to assume that the impact of price changes is an automatic effect seems more appropriate than to include them among the discretionary effects.

The multipliers for the various types of budget changes differ, of course, and these and the leakage coefficients are given in Table 1. The consumption coefficient is small, because $\alpha$ is the ratio of changes in personal consumption to changes in total private income minus only direct household taxes, a definition required because the model does not include an explicit corporate sector. ${ }^{9}$

TABLE 1

LEAKAGE COEFFICIENTS AND MULTIPLIERS

Leakage Coefficients

Marginal rate of direct taxes on households $\left(t_{d}\right) \ldots \ldots \ldots \ldots \ldots \ldots \ldots \ldots .09$

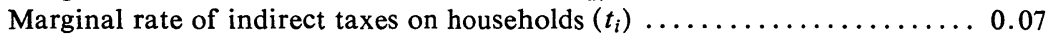

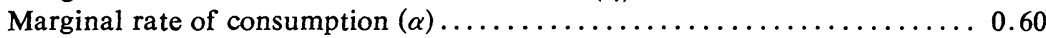

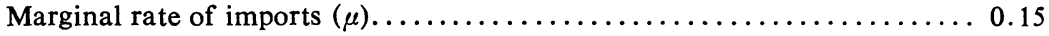

Multipliers for discretionary effects

Changes in the volume of government domestic purchases $\left(d g^{d}+d l\right) \ldots \ldots 1.75$

Changes in rates of direct taxes on households $\left(y d t_{d}\right) \ldots \ldots \ldots \ldots \ldots \ldots \ldots .0 .84$

Changes in rates of indirect taxes on households $\left(c d t_{i}\right) \ldots \ldots \ldots \ldots \ldots \ldots \ldots$

Multipliers for total effects

Changes in the volume of government domestic purchases $\left(d g^{d}+d l\right) \ldots \ldots 2.04$

Changes in the value of government domestic purchases due to

wage-price changes $\left(g d p_{g}+l d w\right)$ and changes in total direct

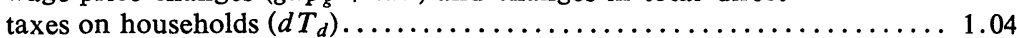

Changes in total indirect taxes on households $\left(d T_{i}\right) \ldots \ldots \ldots \ldots \ldots \ldots \ldots \ldots \ldots$

9 No model can attempt to explain everything, and Hansen's is no exception. Perhaps the most conspicuous omissions are that private investment is treated as an exogenous variable and that the corporate sector is not made explicit. The first can be explained by the inadequate knowledge about investment functions, and the second feature was necessary to maintain comparability among the seven countries, because the national accounts data did not all give adequate information about corporate profits and taxes. 
As the model assumes that the marginal propensities to consume and import and the marginal rates of direct and indirect taxation were constant throughout the period 1952-67, some explanation is necessary. The consumption function remained very stable during the period considered, and no discernible shifting occurred. During three periods-1954/55, 1958/59, and 1962/63 - the rates of change in total private and personal disposable income were substantially less than the changes in consumption, and so for these periods the assumption of a constant propensity to consume is less valid than for the remaining years. The effect of this on the multiplier for the budget changes was compensated by the fact that during these same years the propensity to import changed in the opposite direction, and the two effects tended to cancel one another. For the period as a whole the relationship between imports and GNP also remained stable. The multipliers also depend on the values of the marginal tax rates. These are, of course, based on the automatic response rates of direct and indirect taxes, independent of discretionary changes in the system. While the marginal rates were reasonably stable, they did vary somewhat and in Section 3 we shall discuss this further.

The basic data for estimating the various budget effects come from the recently revised national accounts [13]. Data about discretionary tax changes were provided by the Ministry of Finance. In order to compare the budget impact of one year with another, they were normalized by expressing them as a percentage of the previous year's GNP. (All data are for the fiscal year, which runs from April through March of the following year.) The estimates of the various budget effects given in Table 2 were obtained in this manner. For the data used in Figure 5, however, it was necessary to use the appropriate GNP deflators in order to express the budget effects in constant 1965 prices.

Before we examine the short-term stabilizing effects of the budget, a few remarks should be made about the Japanese economy during the period 1952-67 and about the general importance of the budgetary impact, based on the estimates given in Table 2.

1952 is an appropriate year to begin an analysis of Japanese postwar budget policies, because the adjustments following the cessation of hostilities were generally completed and industrial production had regained its prewar level. From 1952 on the unemployment level remained low and the labor market was generally tight. Urban demand for labor was partially met by a transfer from the rural areas where agricultural employment declined. But around 1960 it became increasingly difficult to withdraw qualified labor from agriculture, and a generally tight market came under greater strain. This was reflected in the rise of consumer prices; measured by the private consumption deflator, the rate had been less than 3 per cent annually before 1960 but it averaged more than 5 per cent afterwards. Thus Japan's demand management problems are more comparable with those European countries which had high rates of employment than with the United States, where unemployment averaged about 5 per cent in the same period.

During the sixteen years of the period surveyed, GNP in constant prices grew 
TABLE 2

EFFECTS OF ANNUAL BUdGET CHANGES AS A PERCENTAGE OF GNP $t-1,1952-67^{a}$

\begin{tabular}{|c|c|c|c|c|c|c|c|c|c|c|c|c|c|c|c|c|c|}
\hline & 1952 & 1953 & 1954 & 1955 & $\underline{1956}$ & 1957 & $\underline{1958}$ & 1959 & 1960 & $\underline{1961}$ & 1962 & 1963 & 1964 & 1965 & 1966 & 1967 & Ave. \\
\hline Total effect of public sector & 1.6 & 2.3 & 0.5 & 3.0 & -4.1 & 0.8 & 2.8 & 2.3 & 0.0 & 1.6 & 5.5 & 1.6 & 2.5 & 3.5 & 2.4 & 2.2 & 1.8 \\
\hline $\begin{array}{l}\text { Government enterprise and public } \\
\text { corporation investment }\end{array}$ & 1.1 & 1.4 & -0.1 & 1.1 & 0.6 & 1.3 & 0.7 & 0.9 & 0.7 & 2.4 & 1.7 & 1.4 & -0.2 & 1.6 & 1.1 & 1.1 & 1.1 \\
\hline $\begin{array}{l}\text { Changes in government enterprise } \\
\text { and public corporation stocks }\end{array}$ & 0.2 & -1.4 & -0.3 & 3.5 & -2.1 & -0.8 & 0.5 & 0.2 & 0.0 & -0.6 & 0.4 & -0.6 & 1.1 & 0.1 & 0.0 & 1.1 & 0.1 \\
\hline General government & 0.4 & 2.2 & 1.0 & -1.6 & -2.6 & 0.2 & 1.6 & 1.2 & -0.7 & -0.2 & 3.4 & 0.8 & 1.6 & 1.8 & 1.3 & 0.0 & 0.6 \\
\hline $\begin{array}{l}\text { Local government } \\
\text { Investment expenditure }\end{array}$ & -0.3 & -0.7 & 0.7 & -1.2 & -0.7 & 0.0 & 1.1 & 0.2 & 0.5 & 1.0 & 1.8 & 0.8 & 1.1 & 0.8 & 0.8 & 0.3 & 0.4 \\
\hline & -0.7 & 1.3 & 0.2 & -0.8 & -0.8 & 0.9 & 0.9 & 0.4 & 0.8 & 1.0 & 1.5 & 0.3 & 0.7 & 0.5 & 0.7 & 0.5 & 0.5 \\
\hline Current expenditure (volume) & -1.2 & -2.2 & 0.9 & -0.7 & -0.1 & -0.3 & 0.9 & 0.4 & 0.7 & 0.9 & 1.0 & 1.0 & 0.8 & 0.7 & 0.6 & 0.8 & 0.3 \\
\hline Indirect taxes & -1.0 & -0.6 & -1.2 & 0.2 & -1.0 & -0.6 & -0.8 & -0.8 & 1.5 & -1.3 & -0.6 & -0.8 & -1.0 & -0.5 & -0.9 & -1.3 & -0.9 \\
\hline Direct household taxes & 0.6 & -0.3 & 0.4 & 0.2 & 0.6 & -0.5 & 0.0 & -0.2 & -0.2 & -0.4 & -0.5 & -0.2 & -0.1 & -0.4 & -0.1 & -0.3 & -0.1 \\
\hline Wage and Price changes & 2.0 & 1.0 & 0.4 & 0.3 & 0.5 & 0.6 & 0.1 & 0.4 & 0.7 & 0.8 & 0.4 & 0.5 & 0.8 & 0.5 & 0.6 & 0.5 & 0.6 \\
\hline Social security & 0.4 & 0.1 & 1.0 & -0.2 & -0.2 & 0.0 & 0.1 & 0.0 & -0.1 & -0.1 & 0.0 & 0.0 & 0.1 & -0.3 & -0.1 & 0.0 & 0.0 \\
\hline Central government & 0.2 & 2.8 & -0.8 & -0.2 & -1.6 & 0.3 & 0.4 & 0.9 & -1.0 & -1.1 & 1.6 & 0.0 & 0.4 & 1.3 & 0.6 & -0.3 & 0.2 \\
\hline Discretionary & 3.4 & 4.9 & 0.0 & 0.7 & 0.2 & 1.4 & 0.8 & 1.4 & 0.7 & 0.9 & 2.1 & 1.3 & 0.7 & 1.1 & 1.2 & 0.5 & 1.3 \\
\hline $\begin{array}{l}\text { Investment expenditure } \\
\quad \text { (volume })\end{array}$ & 0.9 & 0.9 & 0.3 & -0.3 & -0.2 & 0.6 & 0.6 & 1.0 & 0.6 & 0.6 & 1.0 & 0.6 & 0.4 & 0.6 & 0.3 & 0.2 & 0.5 \\
\hline Current expenditure (volume) & 0.9 & 2.3 & -0.3 & 0.4 & 0.0 & 0.2 & 0.1 & 0.5 & 0.1 & 0.2 & 0.4 & 0.5 & 0.2 & 0.4 & 0.3 & 0.3 & -0.4 \\
\hline Indirect taxes & -0.2 & 0.7 & -0.4 & 0.0 & 0.1 & -0.4 & 0.1 & -0.2 & -0.1 & -0.2 & 0.4 & 0.0 & -0.1 & 0.0 & 0.2 & -0.1 & 0.0 \\
\hline Direct household taxes & 1.7 & 1.0 & 0.4 & 0.6 & 0.2 & 0.9 & 0.0 & 0.2 & 0.0 & 0.3 & 0.2 & 0.3 & 0.2 & 0.2 & 0.4 & 0.2 & 0.4 \\
\hline Automatic & -3.1 & -2.1 & -0.7 & -0.9 & -1.8 & -1.1 & -0.5 & -0.6 & -1.7 & -2.0 & -0.5 & -1.3 & -0.3 & 0.1 & -0.7 & -0.8 & -1.1 \\
\hline Taxes & -3.8 & -2.7 & -0.9 & -1.0 & -2.1 & -1.4 & -0.5 & -0.8 & -2.1 & -2.4 & -0.7 & -1.6 & -0.7 & -0.1 & -1.0 & -1.0 & -1.4 \\
\hline Wages and price changes & 0.6 & 0.6 & 0.2 & 0.2 & 0.3 & 0.3 & 0.0 & 0.2 & 0.4 & 0.4 & 0.2 & 0.3 & 0.4 & 0.3 & 0.3 & 0.2 & 0.3 \\
\hline
\end{tabular}

a All data are on a fiscal year basis, April through March of the following year. Sums and averages may not add due to rounding. 
by an average rate of 9.6 per cent which was more than 50 per cent higher than in the Western country with the next highest growth rate, Germany. The expansionary impact of budget changes in the public sector accounted for an estimated 1.8 percentage points, or about one-fifth, of this growth rate (see Table 2), a proportion comparable with that in several Western countries but rather higher than in Germany or the United States. However, because of the small size of Japan's public sector relative to other countries, the expansionary budgetary policies have been more important than elsewhere in accounting for the average growth rate, but they have still not been a particularly large factor. It should be noted that the investment expenditures of government enterprises and public corporations accounted for 1.1 per cent, so that general government's contribution was rather smaller than in most Western countries. Of the remaining. average expansionary effects from government budget changes, neither stock accumulation nor the social security system contributed significantly, the latter reflecting its general design to be self-financing in the long run. Local government on the average added more ( 0.4 per cent of GNP) than central government $(0.2$ per cent), which is also consistent with our previous comment about the relative size of expenditures by the two government sectors. The impact of discretionary changes in expenditures and taxes was generally expansive but was nearly offset by automatic tax increases (about which more in the next section).

\section{AN EVALUATION OF SHORT-TERM STABILIZATION}

Short-term fluctuations have been as strong and occasionally stronger in Japan during the period surveyed than in the two Western countries-Germany and the United States-which experienced similarly large peak-to-trough variations in their growth rates, which sometimes amounted to 8 or 9 per cent of GNP. Acknowledging that the average growth of 9.6 per cent was exceptionally high, it is nevertheless of interest to assess the impact which budget policies had on either dampening or reinforcing the short-term disturbances. In this section we shall investigate the effect of the entire public sector and we shall also look at the impact of individual government sectors; we shall separate the impact of discretionary budget changes from the automatic or built-in stabilizing effects where possible, and discuss briefly tax elasticities. The norm for comparison in this section shall be the average growth rate. We would argue that ceteris paribus, a stable growth rate is desirable; we recognize, however, that merely dampening potential cyclical swings is not the only relevant criterion by which the impact of budget policies should be judged, and Section 4 deals with other aspects of economic stability.

The short-term stabilizing effect of budget changes cannot be compared with actual GNP, because actual GNP is itself influenced by budget policies. We can however construct a hypothetical series of GNP by subtracting from the actual GNP growth rate the total effect of budget changes in the public sector for each year. This derived series is called the "pure cycle," because it attempts to estimate what GNP growth would have occurred in the absence of any change in 


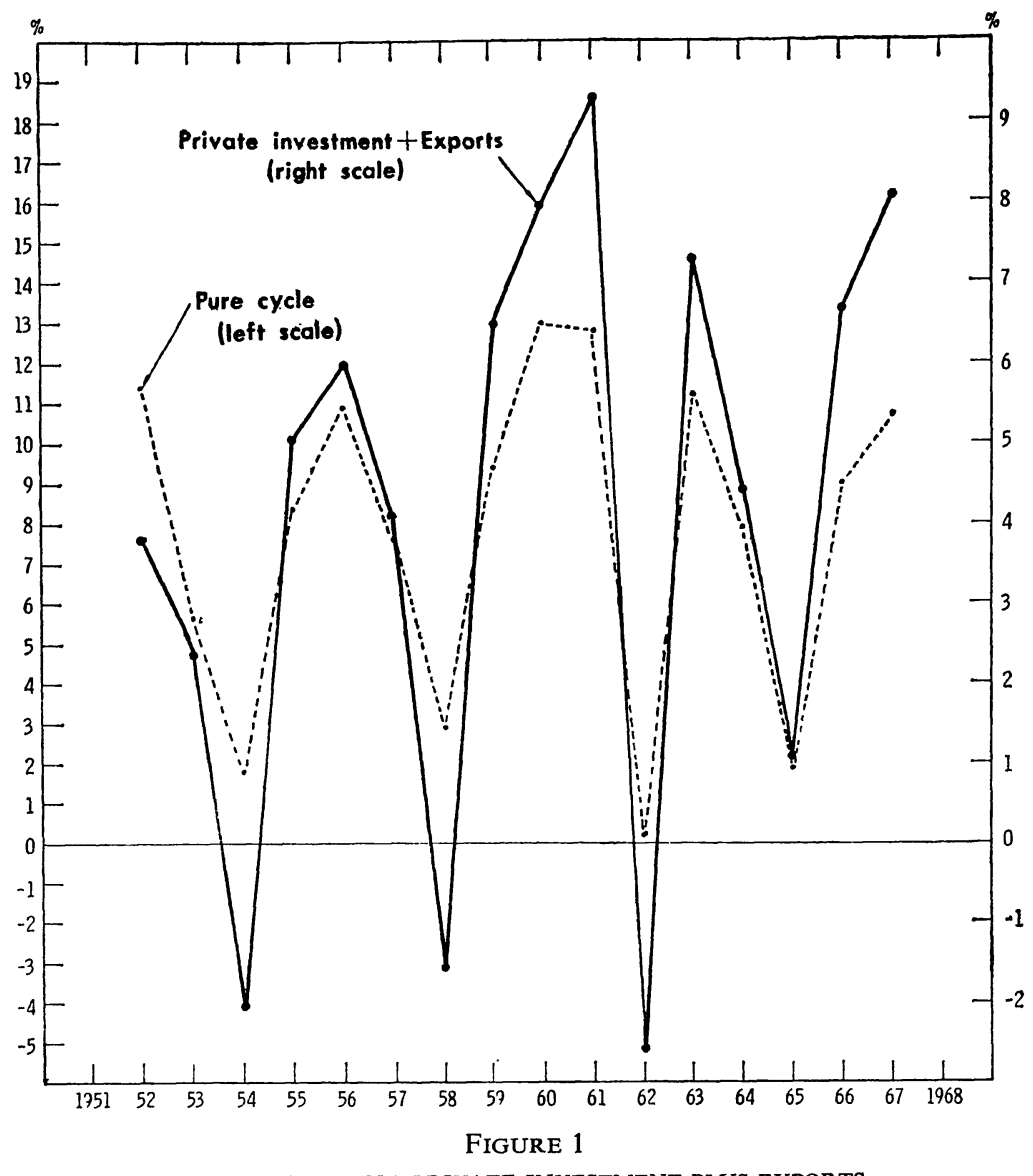

PURE CYCLE AND PRIVATE INVESTMENT PLUS EXPORTS

the budget from one year to the next. This is not the only pure cycle that could be constructed. For a growing economy, in subtracting the budgetary impact from the actual GNP, one might want to omit automatic tax increases and those expenditure increases also deemed automatic in order to concentrate only on the discretionary effects of budget policies. Similarly, a pure cycle which excluded only the discretionary effects would be relevant if one wished to evaluate the importance of the built-in automatic stabilizers. Without actually constructing these other pure cycles, the stabilizing effects of discretionary and automatic budget changes are discussed qualitatively and separately below. It should also be noted that the pure cycle still incorporates the effects of other government policies (e.g., monetary and direct controls) and autonomous forces (e.g., private investment and exports). Hence, the pure cycle is not so "pure," but nevertheless it is a useful analytical device.

After construction of the "pure cycle," a logical next step is to ascertain the strength of the relationship between it and the traditional "exogenous" deter- 


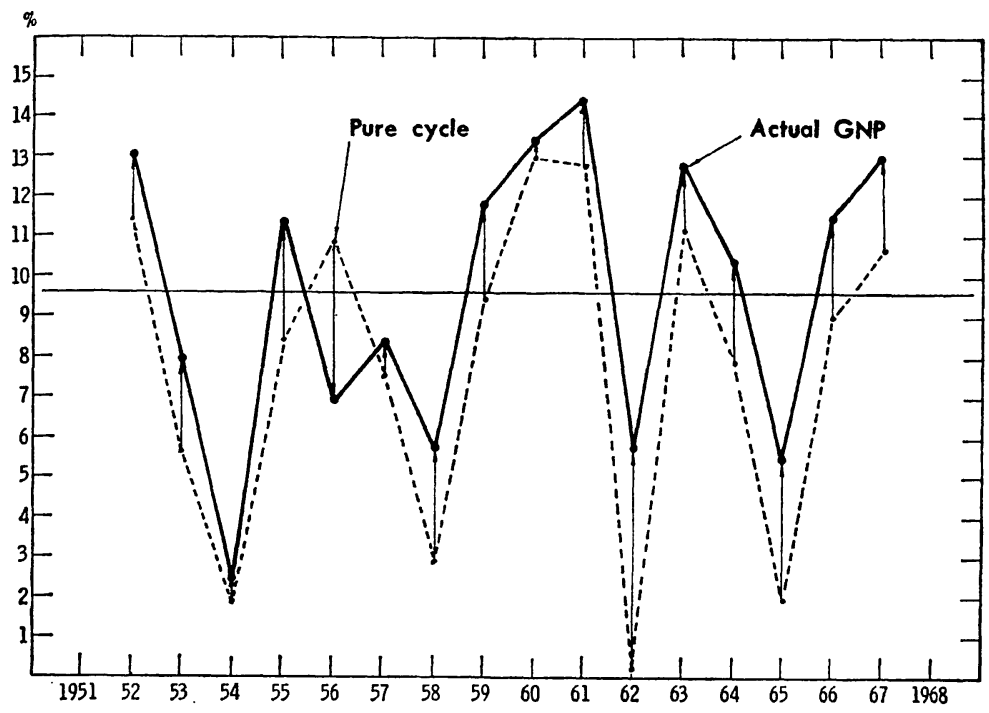

FIGURE 2

BUDGET IMPACT OF PUBLIC SECTOR

minants of fluctuations in demand: private investment and exports. These relationships are given in Figure 1. The co-variation in the two series is strong and, prima facie, one might conclude that Japan witnessed a series of classical business cycles between 1952 and 1967, caused by fluctuations in private investment and exports. Although indeed fluctuations in demand were substantial and in large measure related to variations in exports and, especially, private investment, the latter was itself partly influenced by government policies, principally monetary and credit controls. In Section 4 we shall discuss the methodological problems this raises, but for the present the pure cycle will be used for the basis of comparing the short-term stabilizing or destabilizing impact of budget changes.

We shall define "potential" short-term stabilization as the (absolute) difference between the pure cycle and the average rate of GNP growth. Potential stabilization for the entire period is simply the cumulated sum for the years from 1952 through 1967 . We shall also define a budget effect to be stabilizing if its impact tended to reduce the difference between the pure cycle and the average rate of GNP growth. Figure 2 shows the actual GNP growth rate (solid line), the pure cycle (dashed line), and the average GNP growth rate ( 9.6 per cent). The arrows indicate the direction of the total effects of budget changes in the public sector, and they point from the pure cycle to the actual GNP; their magnitudes are identical with the data given in Table 2.

This visual presentation of the budgetary effects illustrates how they were generally expansive, but it also shows how relatively little they altered the cyclical fluctuations. More precisely, the extent to which they were a stabilizing 
(or destabilizing) factor can be measured as follows. The cumulated amount of potential stabilization was 54 per cent (of a typical year's GNP). Total stabilizing effects, as defined above, amouted to 20 per cent. These were, however, largely offset by the 16 per cent destabilizing effects. Therefore, the net amount of stabilization achieved was not very significant.

It could be, of course, that the impacts of some government sectors were generally anti-cyclical while others were pro-cyclical, thus accounting for the absence of any net stabilizing effects. But if we look at each sector's impact separately, we find no difference between the aggregate performance of the entire public sector and any of the sub-sectors.

Another interesting point from which to appraise the short-term impact of budget policies is to separate the discretionary from the automatic effects. This can be done, however, only for the central government sector, because data about discretionary changes in the other sectors are inadequate. Figure 3 shows the annual changes as previously given in Table 2 (where, it should be recalled, the effects due to wage and price movements are counted among the automatic effects). Clearly, the automatic effects have been stabilizing, as they became much less a "drag" during the four periods of economic slow-down: 1954/55, 1958/59, 1962 , and $1964 / 65$. It is equally apparent that the impact from discretionary budget changes was not anti-cyclical (compare Figures 2 and 3).

The Hansen model does not include in the total effects those due to change in corporate income taxes, although an average leakage is allowed for in the consumption coefficient. Data for both discretionary and automatic tax changes are available, however, and are shown separately in Figure 3. Clearly, the discretionary changes were very small and could have done little to influence investment. The automatic changes were more important and may have prevented demand from slowing down any more than it did in some years, e.g., 1958, 1962, and 1965 , although without knowing more about the determinants of investment we cannot conclude this for certain.

A summary of the average and marginal tax response rates and their long-run elasticities with respect to GNP at factor cost is given in Table 3. We have already indicated that, unlike experience elsewhere, Japan's experience has been unique because taxes declined as a proportion of GNP between 1951 and 1967. This was due to the combined effect of individual tax elasticities and discretionary changes in the rate structure which occurred during the period surveyed.

Direct household rates were reduced in every year during the period except 1960. This explains why in spite of the relatively high long-run elasticity of this tax, its average rate declined. On balance discretionary changes in the structure of direct corporate taxes also tended more to reduce than to increase the marginal response rate, but because the elasticity remained near unity, the average rate did not noticeably change. Although the various indirect tax rates were increased more of ten than they were reduced, their combined average rate declined substantially, because they are imposed on a small number of commodities having low income elasticities, in particular liquor and sugar. While there appears to have been some change in the elasticity from the first half of 


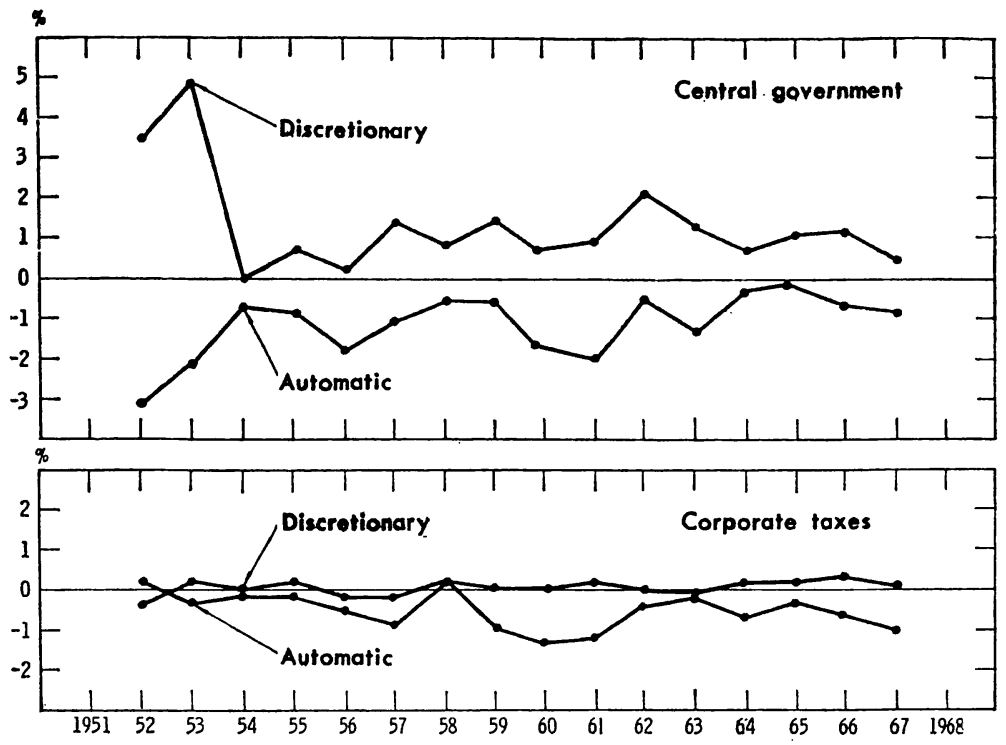

FIGURE 3

DISCRETIONARY AND AUTOMATIC BUDGETING EFFECTS

TABLE 3

AVERAGE TAX ELASTICITIES WITH RESPECT TO GNP AT FACTOR COST, CENTRAL GOVERNMENT

\begin{tabular}{cccc}
\hline & $1952-59$ & & $1960-67$ \\
\cline { 2 - 2 } Indirect taxes & & & \\
Average response & 6.0 & 4.8 & 5.4 \\
Marginal response & 3.7 & 3.8 & 3.7 \\
Elasticity & 0.6 & 0.8 & 0.7 \\
Direct household taxes & & & \\
Average response & 3.4 & 2.9 & 3.2 \\
Marginal response & 7.1 & 5.5 & 6.3 \\
Elasticity & 2.1 & 1.9 & 1.9 \\
Direct corporate taxes & & & \\
Average response & 3.2 & 3.9 & 3.5 \\
Marginal response & 2.8 & 4.8 & 3.8 \\
Elasticity & 0.9 & 1.2 & 1.1 \\
Total tax rates & & & \\
Average response & 12.6 & 11.6 & 12.1 \\
Marginal response & 13.6 & 14.1 & 13.8 \\
Elasticity (weighted) & 1.1 & 1.2 & 1.1 \\
\hline
\end{tabular}

Source: Appendix, Tables 5-7. 
the period to the last half for each of these three categories of taxes, on balance the (weighted) elasticity of the central government tax system does not appear to have changed significantly and remains slightly greater than unity. ${ }^{10}$

All three taxes-direct, personal and corporate, and indirect-operate anticyclically. Tax collections do not lag far behind actual changes in GNP, and thus this inherently stabilizing system is not diminished by undesirable lags as is the case in some countries, e.g., in the United Kingdom some taxes are collected with so much delay after the income base has changed that they are definitely pro rather than anti-cyclical. As might be anticipated, corporate taxes respond more to change in GNP than do direct taxes on households but the tax is not the cause, rather it is because corporate profits vary much more than does personal income. Indirect taxes are also quite sensitive to changes in GNP but less so than for the other two kinds of taxes (see Appendix, Tables A6-A8).

These findings generally agree with the more disaggregated study by Ishi [4], who concluded that the tax-income elasticity for all direct taxes was roughly 1.5 , which is identical with the (weighted) elasticity which can be obtained from the data in Table 3. For the indirect taxes he found the overall elasticity to be about unity, which is higher than our results and not consistent with the observed decline in indirect taxes as a proportion of GNP which occurred between 1951 and 1967 (see Table A2).

\section{EVALUATING ECONOMIC STABILITY AND BALANCED GROWTH}

In this section we shall assess the budget impact in relation to the desire to achieve balanced long-term growth. In the previous section we found that the effect of budget changes did little to mitigate against the sharp short-term fluctuations in GNP. If a longer-term perspective is used instead, the budget impact contributed in a positive manner. This accords with the official view of authorities in the Japanese Planning Agency who have explained that the government's policy has indeed "not been designed for stimulating rapid growth but rather for attaining balanced growth..." [17, (43)] (italics added).

What constitutes "balanced" growth is of course debatable. One criterion which has gained use elsewhere is the concept of the "full-employment potential" which was introduced in President Kennedy's first Economic Report to Congress [19, (52)]. It was designed to highlight how far the actual performance since 1955 had fallen short of the full economic potential of the United States and to illustrate why special government policies were required to achieve a high level of employment. Undeniably the need for generally more expansive budget policies was real, because after 1955 the unemployment rate continually exceeded 4 per cent and surpassed 7 per cent during the 1958 and 1961 reces-

10 The reader may notice in Table 3 that the average ratio of all taxes to GNP at factor cost declined from 1952-59 to 1960-67 although the overall elasticity is greater than one. The explanation is that the high elasticity of direct household taxes did not cause the average rate to increase due to the discretionary tax cuts, and this when combined with the general inelasticity of the indirect tax system caused the average rate to decline although the overall elasticity still remained greater than unity. 
sions. After considerable congressional and public debate, a series of exceptional tax reduction laws were passed, which substantially reduced direct taxes on both households and corporations, and which would eventually eliminate most federal indirect taxes. The impact of these discretionary measures during 1964 and 1965 finally helped boost the American economy back to a high level of employment, but during the eleven years which had passed since it had last operated at what for the United States can be considered its full economic potential (i.e., about 4 per cent unemployment), the cumulated gap between actual and potential GNP amounted to nearly 50 per cent of a typical year's potential full employment output (measured at constant 1958 prices).

Both public and private estimates of potential output now exist for Japan. The official ones [12], [14] and [15] were not, however, known to the authors when this study was begun, and the estimates used are based on those made by professor Lundberg [8] in his study of the problems of economic instability faced by several major countries in the postwar period. Although some minor differences exist, Professor Lundberg's ratio of actual to potential output is generally in accord with the official estimates. His study provides estimates for the years 1951-64: using his method, we have extrapolated through 1967. He defines potential or full employment output to be the combination of an unemployment rate of 2 per cent, which he considers to be "the minimum feasible unemployment rate to be applied uniformily for calculating the potential or full employment labor forces" [7, (99)], and the long-run trend of labor productivity. His estimates for Japan imply that the annual rate of growth of potential GNP was about 8 per cent before 1957 and rose to above 10 per cent afterwards. As the labor force increased more rapidly before 1957 than after (approximately 2 per cent and 1 per cent, respectively), his estimates also imply that a substantial shift in the trend of labor productivity occurred around 1957 which the remarkably growing use of capital intensive techniques permitted.

Figure 4 compares Professor Lundberg's estimates of potential output with the actual growth of GNP from 1951 through 1967 (at constant 1965 prices). Estimates of potential output are, of course, somewhat problematic, because they are not independent of economic policy; government policy affects the distribution of output between consumption and investment and this clearly influences the rate of growth of the labor force and productivity. But in spite of these limitations, the estimates provide a useful basis for evaluating the budgetary impact if they are discussed in relation to other policy objectives and instruments.

The objectives of economic policy are everywhere numerous, and the instruments used to achieve them are even more so. ${ }^{11}$ Nevertheless, four goals predominate, although others may temporarily replace some of them from time to time or one objective may completely dominate for a short while to the detriment of maintaining an appropriate balance among the others; this, we shall see, has typically been the case with Japan. The four principal items which are of

11 One study of economic policy [6, (148-149)] lists eight major conjunctural and structural objectives and four minor targets; and it enumerates no fewer than sixty-five instruments available to achieve them. 


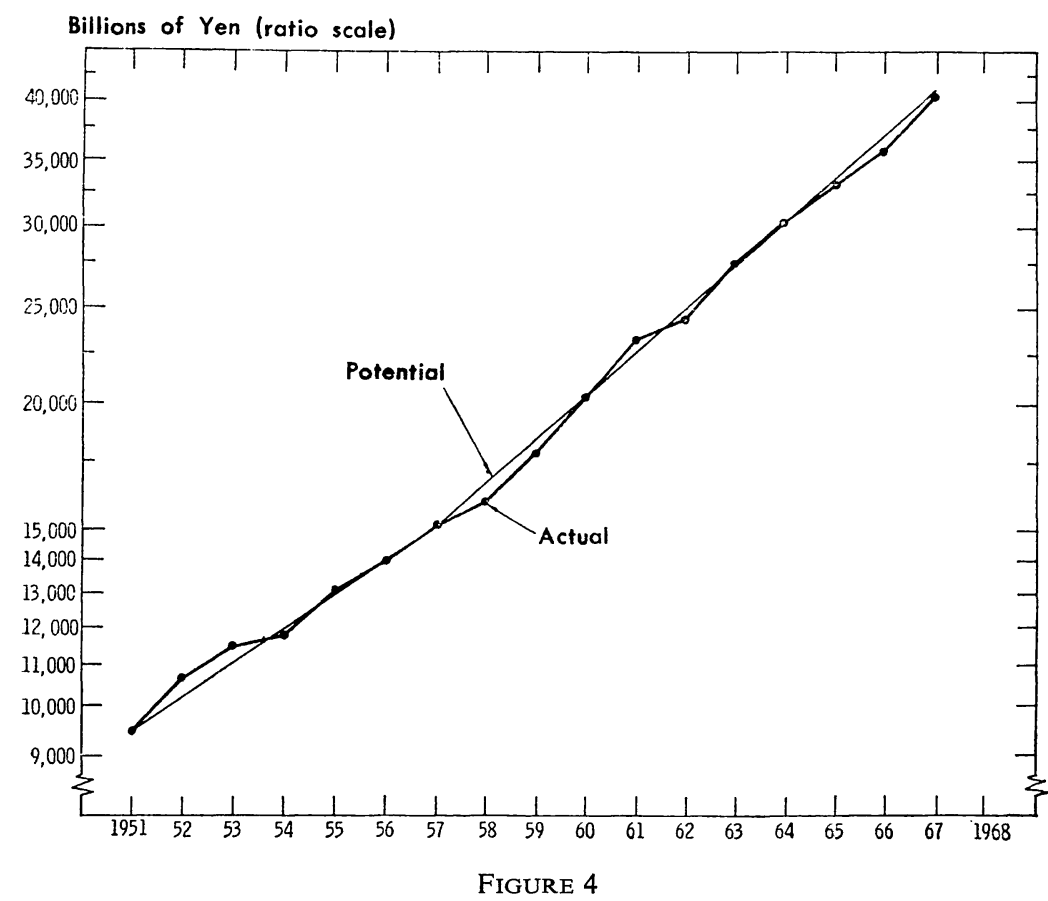

GROSS NATIONAL PRODUCT, ACTUAL AND POTENTIAL: CONSTANT 1965 PRICES

primary concern to all governments are growth, employment, prices, and balance of payments. Changes in budgetary expenditures and tax rates are only some of the means by which economic policies influence the economy generally and the level of demand, particularly its composition. Monetary policies, direct controls, and changes in the institutional framework are other important categories of instruments at the disposal of governments in their attempt to achieve an appropriate balance among the desired objectives. This study only attempts to quantify the effects of budgetary policies, although other policies-notably monetary-will be mentioned where appropriate.

For the reasons explained in Section 3, the hypothetical pure cycle is useful to assess the budgetary impact on balanced growth. In Figure 5 actual GNP and the pure cycle are expressed as percentage deviations from potential output, shown for convenience as a horizontal line.

If Figures 2 and 5 are compared we can easily perceive a striking difference between the absence of any general tendency of the budget impact to dampen short-term fluctuations in GNP (Figure 2) and a definitely stabilizing effect if the longer-term criterion of potential output is used (Figure 5). Later, a quantitative evaluation of this will be given, but first a few general comments about economic development in Japan during the period 1952-67.

The typical sequence of events, which was repeated five times during the period surveyed, was the following. A period of rapid expansion occasioned by 


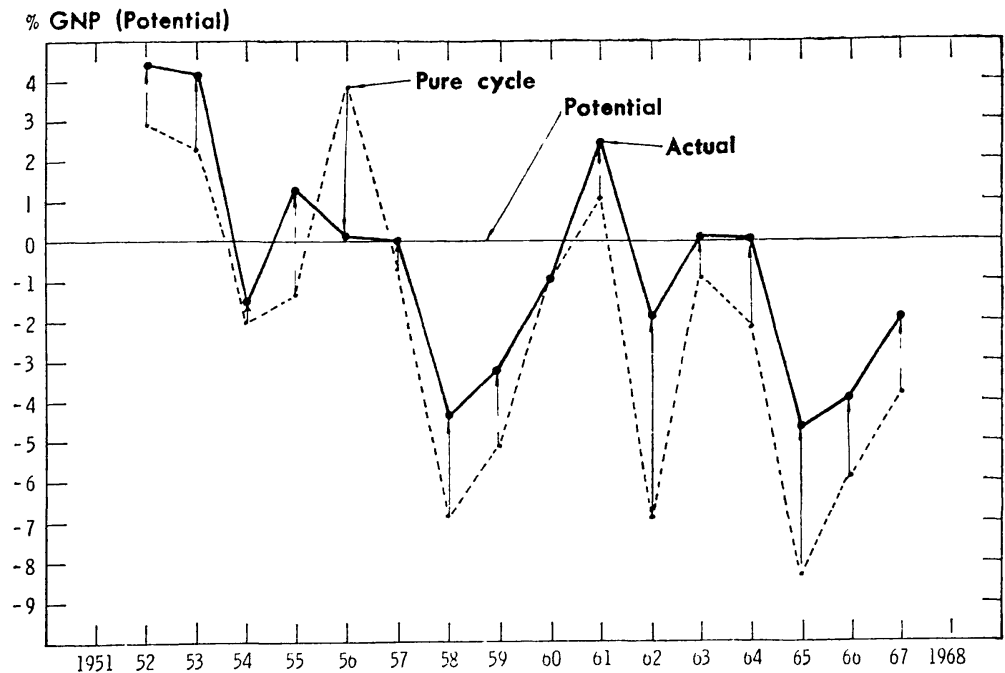

FIGURE 5

DEVIATIONS OF ACTUAL GNP AND THE PURE CYCLE FROM POTENTIAL OUTPUT

particularly strong private investment and exports would lead to higher than normal imports, a deteriorating balance of trade, and ultimately a decline in Japan's international monetary reserves. This led the government four times to implement policies aimed at restricting import demand in order to redress the trade balance and restore the lost reserves. Once sufficient cooling off had been achieved, policies were relaxed and Japan would begin again its own version of a "stop/go" syndrome-but with the important difference that the average growth rate remained phenomenally high, whereas the comparable British experience was accompanied by one of Europe's lowest growth rates. It is important to note, however, that the postwar "recessions" were preceded on three occasions-1952/53,1957/58, and 1961/62 - by a world-wide weakening of export sales which particularly affected Japan. Thus, it would not be correct to conclude that the self-enforced economic slow-downs were entirely the result of domestic policies; the change in export demand was a major factor which led the authorities to undertake the restrictive policies: mainly monetary although direct import controls were also used but to a decreasing degree throughout the period. A brief description of actual developments from 1952 through 1967 will illustrate the above generalization, and will be helpful in putting a proper perspective on the impact of Japanese budgetary policies.

The years 1952 and 1953 were the height of the Korean War "boom," when the pure cycle exceeded potential output, and both conjunctural and long-term considerations called for deflationary policies. Both monetary and budgetary policies remained expansionary, however, thus adding to the already overheated situation. This was reflected in a large increase in consumer prices during 1952 ( 5 per cent) and an even larger amount the following year ( 8 per cent). During 
1953 the balance of trade situation deteriorated rapidly, the result of stagnating exports due to the end of the Korean boom and rapidly rising imports, causing a decline of about $\$ 100$ million or 10 per cent of Japan's international reserves. Tight monetary policies were put into effect during 1953 and were kept on throughout most of 1954. The previous expansionary budget effects of 1952 and 1953 were reduced to a negligible amount for 1954 through discretionary changes in both expenditures and taxes, although the impact of the latter was somewhat offset by the automatic stabilizing effect of the tax and social security system. The deflationary policies were successful and Japan's international reserves were quickly rebuilt during 1954 , which permitted the authorities to relax both monetary and budgetary policies in 1955. An OECD Economic Survey of Japan explained, "The main reason why monetary policy has worked so efficiently in Japan lies probably in the system of strict quantitative controls, implying from time to time drastic cuts in the amounts of new loans granted by banks, applied by the Bank of Japan" [18, (37-38)].

The easy policies were continued until 1957, when once again the combination of a somewhat overheated economy with rapidly rising imports and stagnating exports led to a loss in reserves amounting to about $\$ 100$ million.

It should be noted, however, that the budget impact in 1956 had a strong dampening effect, mostly due to inventory depletion and the strong automatic increase in tax revenue; and in 1957 the budget effect was virtually nil. Monetary policies were increasingly tightened throughout 1957 and then slowly removed after the middle of 1958. As the monetary policies were relaxed, the economy regained and then surpassed its full employment potential, setting the stage for another "stop/go" sequence.

The over-heating in 1961 was accompanied by a loss of about $\$ 400$ million in reserves, but this was quickly rebuilt in 1962 when monetary and import controls were enforced. The budgetary impact in 1962 was a countervailing force, due both to discretionary changes in expenditures and taxes and, especially, the reduced "drag" from automatic tax increases. The tight policies were quickly reversed when the reserves began to be replaced.

The period of relaxed policies lasted until the middle of 1964, at about which time declining reserves occurred once again and led the authorities to introduce restrictive monetary and import policies. The budgetary impact, however, remained expansionary, the increase being substantial in 1965 during the period of self-imposed economic slow-down, and helped maintain Japan closer to its full potential than it would have been otherwise because of the deflationary monetary policies.

Monetary policies were relaxed during 1965 and the sequence began again, with the consequence that enough overheating had begun to occur in 1967 to lead the authorities once more to tighten monetary policies, although the loss in reserves was only negligible that year.

If the budgetary impact appears to have been a definitely stabilizing factor during the periods of below potential growth, the same cannot be said for it during most of the years when the economy was overheated. Thus, we are led to 
the general conclusion that the budget effects helped lift the economy towards the utilization of its full potential, but few discretionary deflationary budget measures were taken during the periods of excess demand-although, of course, the automatic effects helped to dampen what would have been even larger inflationary effects from the budget.

We will now give a quantitative evaluation of the budgetary impact with respect to potential output. However, the fact that the pure cycle retains the effects of other government policies raises certain methodological problems about attempting to assess the stabilizing (or destabilizing) impact of budgetary policies alone. For example, the budgetary impact may be destabilizing (i.e., causing demand to diverge from potential GNP), but this may be the desired intent of policies aimed at cooling off an overheated economy. Or, it may be that if other policies could be quantified, they might have created the original situation without which the budget alone would have had a stabilizing impact. The reverse is equally possible, because budget policies may get credit for stabilization which properly belong to other economic policies. We cannot eliminate this dilemma because we have not attempted to quantify the impact of other policies, notably monetary, although we assume their effect has sometimes been significant. We have, however, attempted to discuss their impact in a qualitative way, and thus indicate how our final evaluation of budgetary policies alone might need to be modified.

This does not exhaust all the conceptual problems; at least one more should be discussed. In cases where the budgetary impact is in the right direction but exceeds the amount necessary to reach potential output, how should the total effect be counted? It seemed sensible to divide the impact into two components: the part that was stabilizing, and the other which overshot and had destabilizing effects. In fact, the only clear case of this occurred in 1955, when the total effect was about twice as strong as necessary to push the economy towards its full potential.

With these definitions and caveats in mind, the data of Table 4 can be interpreted. It summarizes the pertinent relationships on a cumulated basis for the sixteen-year period. The cumulated amount of potential stabilization (Item 1) amounted to about 55 per cent (of a typical year's output). By far the major portion of this occurred at times when the economy was below its potential, although the economy was potentially overheated in four of the sixteen years. If we look at the (gross) stabilizing effects alone (Item 2), we find that about twice as much occurred when the economy was below its potential as when it was above it. But these desirable effects were somewhat diminished by the occasions when the budget impact was destablizing (Item 3); and we notice that this was due more to excessive expansionary effects, than to dampening effects when the economy was below its potential. Thus, the net stabilizing effects were less than they would have otherwise been (Item 4) but were nevertheless substantial. On a net basis the budget impact helped to reduce the cumulated gap between the pure cycle and the full employment potential by about 37 per cent (Item 6). 
TABLE 4

TOTAL EFFECTS AND ECONOMIC STABILIZATION, 1952-67

(EXPRESSED AS A PERCENTAGE OF POTENTIAL GNP)

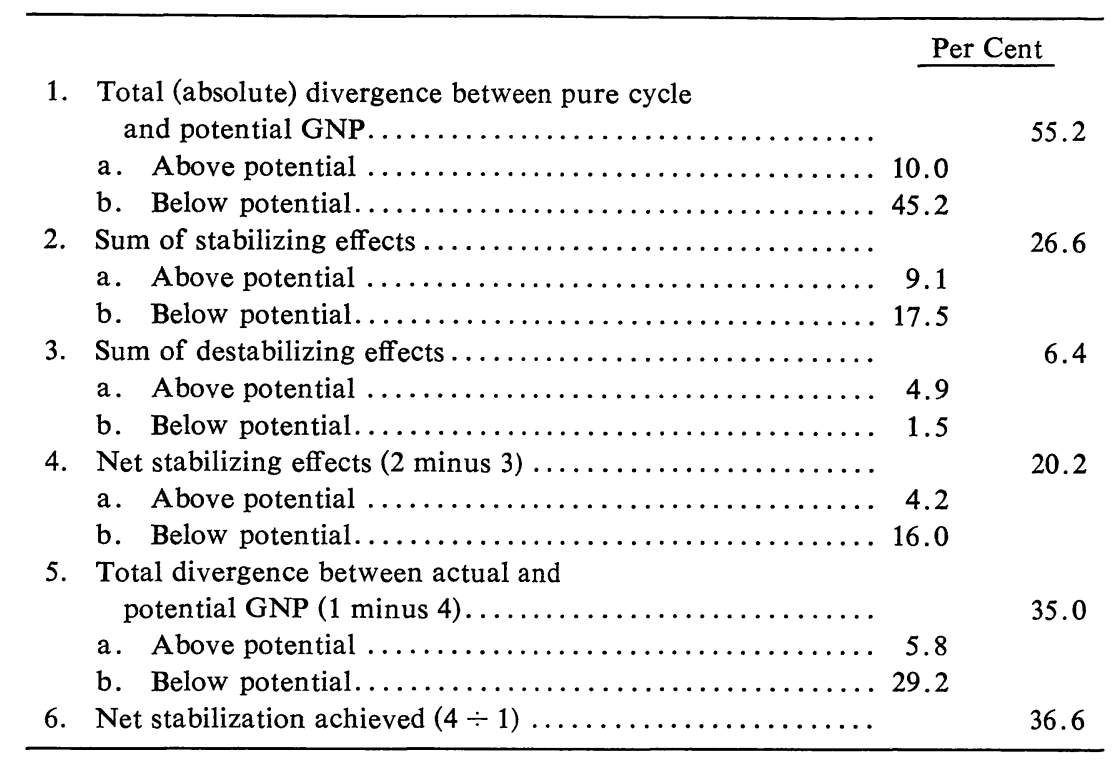

\section{SUMMARY AND CONCLUSION}

Our purpose has not been to analyze the intent of budget policies but rather to estimate their effect. Policy statements issued by governments everywhere generally tend to accord with what might be agreed are desirable policies. But ex ante proclamations of intent sometimes turn out never to have materialized. Hence we have not concerned ourselves with the public pronouncements but have instead estimated the actual impact of budgetary policies on domestic demand and their relation to both short and long-term stabilization.

We have provided a number of different insights into the relative importance of various kinds of budget changes during the period 1952-67. Considering the comparatively small size of the public sector in Japan, it has had an expansionary impact which was relatively larger in accounting for the very high GNP growth rate than in the West. The budgetary impact did little on balance to dampen the rather strong and frequent short-term swings in demand. If the criterion of helping to achieve the longer-term objective of the full utilization of Japan's potential resources is used instead, however, a different conclusion is reached. In this case we found that the Japanese budgetary policies were a considerable stabilizing factor. In this respect, Japan offers an example that is nearly the exact opposite of the United States, where the impact of the budget through both discretionary and automatic changes contributed considerably to smoothing out fluctuations in demand which would have otherwise been even 
TABLE 5

SHORT AND LONG-TERM STABILIZING IMPACT OF BUDGET CHANGES (CUMULATED PERCENTAGE OF GNP FOR 1955-65)

\begin{tabular}{l|c|c|c|c}
\hline & \multicolumn{2}{|c|}{ Short-Term } & \multicolumn{2}{c}{ Long-Term } \\
\cline { 2 - 5 } & $\begin{array}{c}\text { Potential } \\
\text { Stabilization }\end{array}$ & $\begin{array}{c}\text { Net } \\
\text { Stabilization }\end{array}$ & $\begin{array}{c}\text { Potential } \\
\text { Stabilization }\end{array}$ & $\begin{array}{c}\text { Net } \\
\text { Stabilization }\end{array}$ \\
\hline Belgium & 24 & 6 & 40 & 4 \\
France & 14 & 2 & 24 & 7 \\
Germany & 33 & 13 & 20 & 3 \\
Italy & 21 & 9 & 44 & 9 \\
JAPAN & 38 & 6 & 38 & 19 \\
Sweden & 22 & 8 & 21 & 13 \\
United Kingdom & 15 & 1 & 19 & 5 \\
United States & 48 & 19 & 55 & 10 \\
\hline
\end{tabular}

stronger than they actually were but where little was done to make full use of the country's long-run potential.

These two measures of stabilization are both relevant and related. Most economists would agree that ceteris paribus, a stable rate of economic growth is preferable to one which fluctuates, because of the side effects the latter can have on employment, prices, and balance of payments stability. But most would also agree that this is of less concern if the country is not functioning near its potential capacity. These two measures of stabilization-short and long-term-are available for the seven countries in the original Hansen study, and in Table 5 Japan has been added with the data appropriately adjusted and accounted for the same period $1955-65$.

No two countries are quite alike in their experiences with short- and longterm stabilization, but a lengthy comparison is unnecessary. Suffice it to say that Japan had a relatively large amount of both kinds of potential stabilization but the budgetary impact helped much more to keep the economy functioning close to its full capacity utilization than it did to help smooth out potential short-run fluctuations in demand which were sometimes adversely affected by budget changes. Nevertheless, Japan's achievement of short-term stabilization was only somewhat below par as compared with the performance of the seven other countries. ${ }^{12}$ Its achievement of long-term stabilization was superior and only surpassed by Sweden.

Perhaps this is not a surprising conclusion. For Japan's postwar growth has been phenomenally high. When the periods of overheating (which as we have seen were almost always accompanied by an exogenously determined slowdown in exports) called forth deflationary policies, more often monetary than budgetary, the result produced the rather frequent and pronounced swings in output and demand, albeit each short-lived. It used to be said sometimes that a high

12 This conclusion differs from our earlier statement about net short-term stabilization (pp. 9394) because it refers to a different period. 
growth rate would be inevitably accompanied by sharp and frequent cyclical swings; it would be reassuring if Japan could direct its future economic policies towards maintaining its uniquely high growth rate while at the same time achieving a greater degree of stable growth.

University of Michigan, U.S.A.

TABLE A1

GENERAL GOVERNMENT

\begin{tabular}{l|r|r|r|r}
\hline & \multicolumn{2}{|c|}{1951} & \multicolumn{2}{c}{1967} \\
\cline { 2 - 5 } & \multicolumn{1}{|c|}{$\begin{array}{c}\text { Billion } \\
\text { Yen }\end{array}$} & \% GNP & \multicolumn{1}{c}{ 落lion } & \% GNP \\
\hline GNP at market prices & $5,481.5$ & 100.0 & $44,707.6$ & 100.0 \\
1. Total Current Revenue & $1,184.5$ & 21.6 & $8,822.1$ & 19.7 \\
a. Contributions to Social Security & 95.2 & 1.7 & $1,594.2$ & 3.6 \\
b. Other direct taxes on households & 283.3 & 5.2 & $1,742.9$ & 3.9 \\
c. Direct taxes on corporations & 241.3 & 4.4 & $1,763.6$ & 3.9 \\
d. Indirect taxes & 510.7 & 9.3 & $3,356.1$ & 7.5 \\
e. Other income & 54.0 & 1.0 & 365.3 & 0.8 \\
2. Total Current Expenditure & 712.5 & 13.0 & $6,533.8$ & 14.6 \\
a. Goods and services & 555.2 & 10.1 & $3,862.3$ & 8.6 \\
b. Subsidies & 37.6 & 0.7 & 415.3 & 0.9 \\
c. Interest on public debt & 7.3 & 0.1 & 225.9 & 0.5 \\
d. Transfers & 112.4 & 2.1 & $2,030.3$ & 4.5 \\
3. Net Savings (1 minus 2) & 472.0 & 8.6 & $2,288.3$ & 5.1 \\
4. Less: Gross fixed asset formation & 263.0 & 4.8 & $2,278.8$ & 5.1 \\
5. Net Lending & 209.0 & 3.8 & 9.5 & 0.0 \\
\hline
\end{tabular}

1 Transfers received plus income from property and entrepeneurship.

Source: Economic Planning Agency, Revised Report on National Income Statistics (195167).

TABLE A2

CENTRAL GOVERNMENT

\begin{tabular}{l|r|r|r|r}
\hline & \multicolumn{2}{|c|}{1951} & \multicolumn{2}{c}{1967} \\
\cline { 2 - 5 } & $\begin{array}{c}\text { Billion } \\
\text { Yen }\end{array}$ & \% GNP & $\begin{array}{c}\text { Billion } \\
\text { Yen }\end{array}$ & \% GNP \\
\hline GNP at market prices & $5,481.5$ & 100.0 & $44,707.6$ & 100.0 \\
1. Current Revenue & & & & \\
a. Direct taxes on households & $(225.7)$ & $(4.1)$ & $1,226.7$ & 2.7 \\
b. Direct taxes on corporations & $(189.9)$ & $(3.5)$ & $1,550.0$ & 3.5 \\
c. Indirect taxes & $(307.4)$ & $(5.6)$ & $1,756.9$ & 3.9 \\
2. Current Expenditure for Goods and & & & & \\
$\quad$ Services & $(142.5)$ & $(2.6)$ & $1,466.8$ & 3.3 \\
3. Gross Fixed Asset Formation & 91.9 & 1.7 & $1,087.2$ & 2.4 \\
\hline
\end{tabular}

Source: Economic Planning Agency, Revised Report on National Income Statistics (195167). 
TABLE A3

LOCAL GOVERNMENT

\begin{tabular}{l|r|r|r|r}
\hline & \multicolumn{2}{|c|}{1951} & \multicolumn{2}{c}{1967} \\
\cline { 2 - 5 } & $\begin{array}{c}\text { Billion } \\
\text { Yen }\end{array}$ & \% GNP & $\begin{array}{c}\text { Billion } \\
\text { Yen }\end{array}$ & \% GNP \\
\hline GNP at market prices & $5,481.5$ & 100.0 & $44,707.6$ & 100.0 \\
1. Current Revenue & & & & \\
a. Direct taxes on households & 57.6 & 1.1 & 516.1 & 1.2 \\
b. Direct taxes on corporations & 51.4 & 0.9 & 213.6 & 0.5 \\
c. Indirect taxes & 203.3 & 3.7 & $1,599.3$ & 3.6 \\
2. Current Expenditure for Goods and & & & & \\
$\quad$ Services & 401.2 & 7.3 & $2,395.5$ & 5.4 \\
3. Gross Fixed Asset Formation & 171.1 & 3.1 & $1,191.6$ & 2.7 \\
\hline
\end{tabular}

Source: Economic Planning Agency, Revised Report on National Income Statistics (1951- ] 67).

TABLE A4

SOCIAL SECURITY, GOVERNMENT ENTERPRISE AND PUBLIC CORPORATION INVESTMENT INCREASE IN STOCKS BY ENTERPRISES AND PUBLIC CORPORATIONS

\begin{tabular}{l|r|r|r|r}
\hline & \multicolumn{2}{|c|}{1951} & \multicolumn{2}{c}{1967} \\
\cline { 2 - 5 } & $\begin{array}{c}\text { Billion } \\
\text { Yen }\end{array}$ & \% GNP & \multicolumn{1}{c|}{$\begin{array}{c}\text { Billion } \\
\text { Yen }\end{array}$} & \% GNP \\
\hline GNP at market prices & $5,436.8$ & 100.0 & $44,707.6$ & 100.0 \\
I. Social Security & & & & \\
A. Total Revenue & 95.2 & 1.7 & $1,594.2$ & 3.6 \\
1. Contribution by employers & n.a. & $(0.9)^{a}$ & 909.6 & 2.0 \\
2. Contribution by insured persons & n.a. & $(0.8)^{a}$ & 684.6 & 1.5 \\
B. Total Expenditure & & & & \\
1. Transfers to households & 89.9 & 1.6 & $1,546.0$ & 3.5 \\
C. Net Savings & 5.2 & 0.1 & 48.2 & 0.1 \\
II. Covernment Enterprise and Public & & & & \\
$\quad$ Corporation Investment & 95.1 & 1.7 & $1,689.4$ & 3.8 \\
A. Central Government & 76.0 & 1.4 & $1,301.4$ & 2.9 \\
B. Local Government & 19.2 & 0.4 & 388.0 & 0.9 \\
III. Government Enterprise and Public & & & & \\
$\quad$ Corporation Change in Stocks & 40.4 & 0.7 & 346.8 & 0.8 \\
A. Central Government & 40.2 & 0.7 & 344.5 & 0.8 \\
B. Local Government & 0.3 & 0.0 & 2.3 & 0.0 \\
\hline
\end{tabular}

a Based on relative shares in 1955.

Source: Economic Planning Agency, Revised Report on National Income Statistics (195167). 
TABLE A5

CENTRAL GOVERNMENT

AUTOMATIC RESPONSE OF TOTAL TAXES

Billion Yen

\begin{tabular}{|c|c|c|c|c|c|c|c|c|c|}
\hline Year & $\begin{array}{c}\text { GNP at } \\
\text { factor cost }\end{array}$ & $\begin{array}{l}\text { Annual change } \\
\text { in GNP }\end{array}$ & Total taxes & $\begin{array}{l}\text { Annual change } \\
\text { in total taxes }\end{array}$ & $\begin{array}{l}\text { Discretionary } \\
\text { change in } \\
\text { total taxes }\end{array}$ & $\begin{array}{l}\text { Automatic } \\
\text { change in } \\
\text { total taxes }\end{array}$ & $\begin{array}{l}\text { Marginal } \\
\text { response } \\
\text { rate }\end{array}$ & $\begin{array}{l}\text { Average } \\
\text { response } \\
\text { rate }\end{array}$ & Elasticity \\
\hline & (1) & $(2)=(1)_{t}-(1)_{t-1}$ & (3) & $(4)=(3)_{t}-(3)_{t-1}$ & (5) & $(6)=(4)-(5)$ & $(7)=(6) /(2)$ & $(8)=(3) /(1)$ & $(9)=(7) /(8)$ \\
\hline 1951 & $4,970.8$ & & 730.0 & & & & & & \\
\hline 1952 & $5,755.3$ & 784.5 & 851.6 & 121.6 & -87.1 & 208.7 & 26.6 & 14.8 & 1.80 \\
\hline 1953 & $6,818.3$ & $1,063.0$ & 952.8 & 101.2 & -126.0 & 227.2 & 21.4 & 14.0 & 1.53 \\
\hline 1954 & $7,079.2$ & 260.9 & 944.0 & -8.8 & -14.0 & 5.2 & 2.0 & 13.3 & 0.15 \\
\hline 1955 & $8,104.2$ & $1,025.0$ & 947.1 & 3.1 & -66.1 & 69.2 & 6.8 & 11.7 & 0.58 \\
\hline 1956 & $9,082.2$ & 978.0 & $1,096.2$ & 149.1 & -14.9 & 164.0 & 16.8 & 12.1 & 1.39 \\
\hline 1957 & $10,258.3$ & $1,176.1$ & $1,215.0$ & 118.8 & -61.7 & 180.5 & 15.3 & 11.8 & 1.30 \\
\hline 1958 & $10,736.7$ & 478.4 & $1,215.2$ & 0.2 & -34.1 & 34.3 & 7.2 & 11.3 & 0.64 \\
\hline 1959 & $12,427.1$ & $1,690.4$ & $1,416.7$ & 201.5 & -9.5 & 211.0 & 12.5 & 11.4 & 1.10 \\
\hline 1960 & $14,776.5$ & $2,349.4$ & $1,826.6$ & 409.9 & 6.6 & 403.3 & 17.2 & 12.4 & 1.39 \\
\hline 1961 & $18,122.8$ & $3,346.3$ & $2,264.3$ & 437.7 & -74.4 & 512.1 & 15.3 & 12.5 & 1.22 \\
\hline 1962 & $19,845.2$ & $1,722.4$ & $2,438.9$ & 174.6 & -114.0 & 288.6 & 16.8 & 12.3 & 1.37 \\
\hline 1963 & $23,520.6$ & $3,675.4$ & $2,783.3$ & 344.4 & -49.8 & 394.2 & 10.7 & 11.8 & 0.91 \\
\hline 1964 & $27,206.9$ & $3,686.3$ & $3,185.8$ & 402.4 & -108.3 & 510.7 & 13.9 & 11.7 & 1.19 \\
\hline 1965 & $30,165.6$ & $2,958.7$ & $3,396.3$ & 210.5 & -111.1 & 321.6 & 10.9 & 11.3 & 0.96 \\
\hline 1966 & $35,268.6$ & $5,103.0$ & $3,773.8$ & 377.5 & -295.6 & 673.1 & 13.2 & 10.7 & 1.23 \\
\hline 1967 & $41,351.5$ & $6,082.9$ & $4,533.6$ & 759.8 & -90.9 & 850.7 & 14.0 & 11.0 & 1.27 \\
\hline
\end{tabular}

Source: Economic Planning Agency, Revised Report on National Income Statistics (1951-67) and estimates of discretionary tax classes furnished by the Ministry of Finance. 
TABLE A6

CENTRAL GOVERNMENT

AUTOMATIC RESPONSE OF INDIRECT TAXES

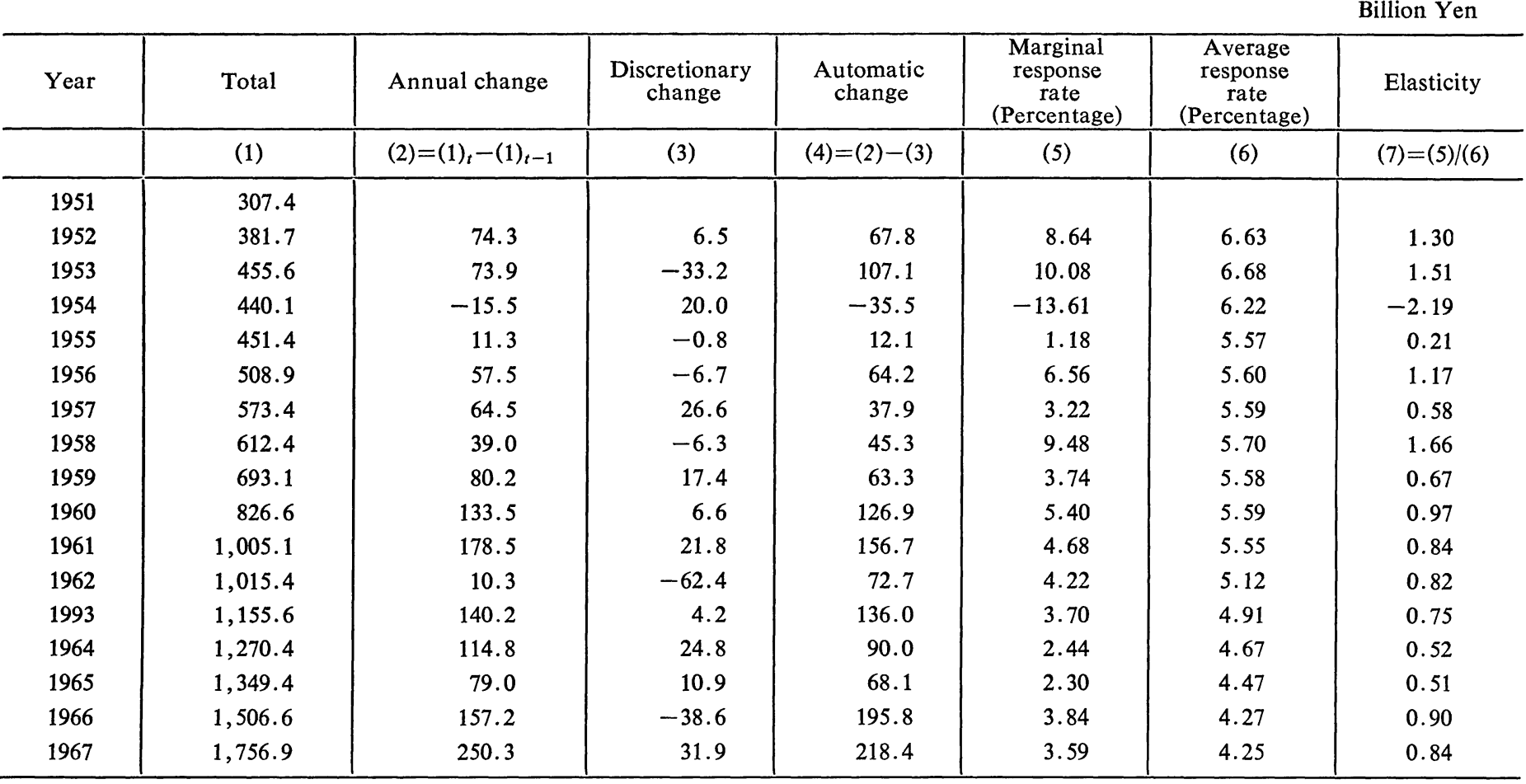

Source: Economic Planning Agency, Revised Report on National Income Statistics (1951-67) and estimates of discretionary tax classes furnished by the Ministry of Finance. 
TABLE A7

CENTRAL GOVERNMENT

AUTOMATIC RESPONSE OF DIRECT TAXES ON HOUSEHOLDS (INC. CHARGES)

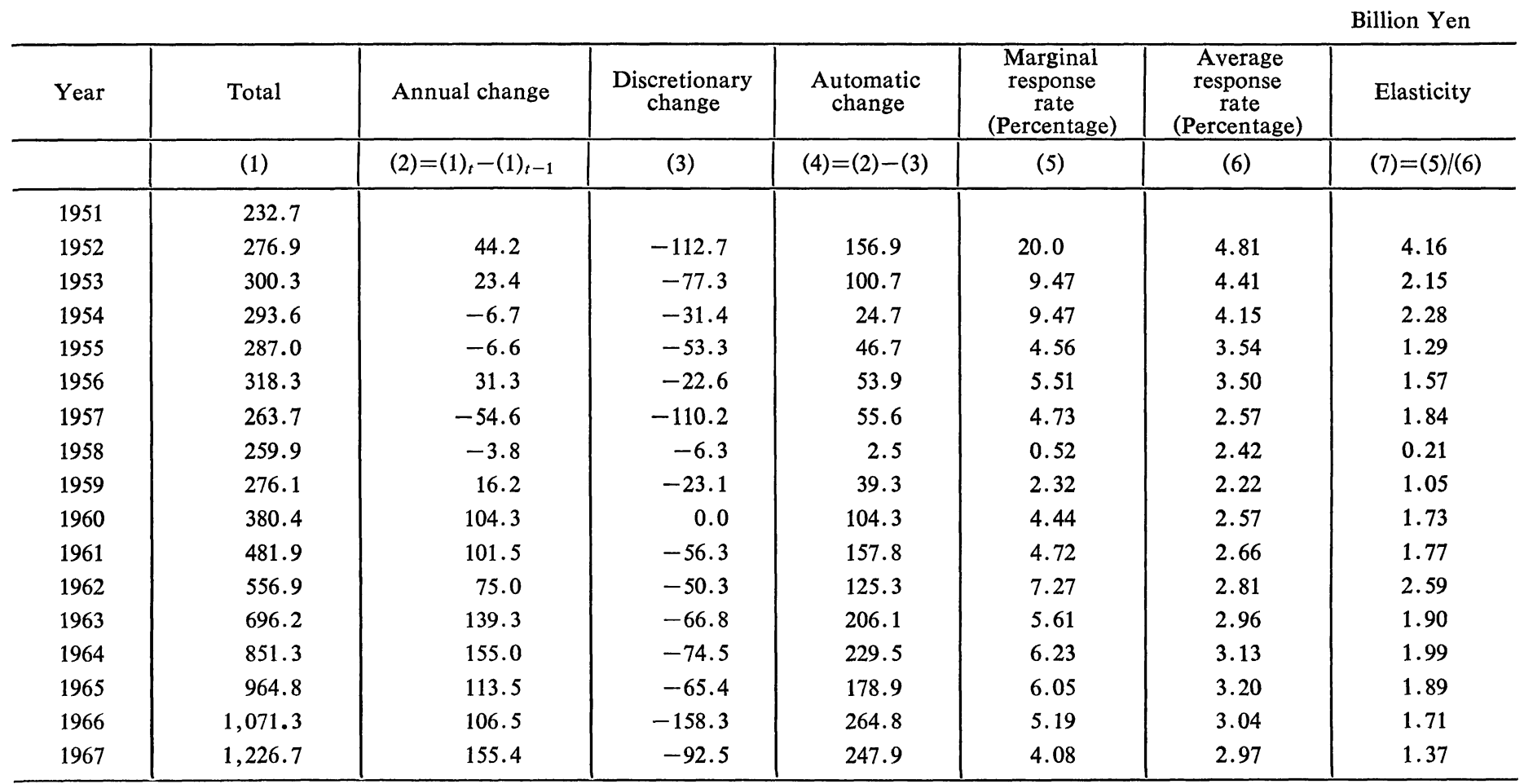

Source: Economic Planning Agency, Revised Report on National Income Statistics (1951-67) and estimates of discretionary tax classes furnished by the Ministry of Finance. 
TABLE A8

CENTRAL GOVERNMENT

AUTOMATIC RESPONSE OF DIRECT TAXES ON CORPORATIONS

Billion Yen

\begin{tabular}{|c|c|c|c|c|c|c|c|}
\hline Year & Total & Annual change & $\begin{array}{l}\text { Discretionary } \\
\text { change }\end{array}$ & $\begin{array}{c}\text { Automatic } \\
\text { change }\end{array}$ & $\begin{array}{c}\text { Marginal } \\
\text { response } \\
\text { rate } \\
\text { (Percentage) }\end{array}$ & $\begin{array}{c}\text { Average } \\
\text { response } \\
\text { rate } \\
\text { (Percentage) }\end{array}$ & Elasticity \\
\hline & (1) & $(2)=(1)_{t}-(1)_{t-1}$ & (3) & $(4)=(2)-(3)$ & (5) & (6) & $(7)=(5) /(6)$ \\
\hline 1951 & 189.9 & & & & & & \\
\hline 1952 & 193.0 & 3.1 & 19.1 & -16.0 & -2.04 & 3.35 & -0.61 \\
\hline 1953 & 196.9 & 3.9 & -15.5 & 19.4 & 1.82 & 2.89 & 0.63 \\
\hline 1954 & 210.3 & 13.4 & -2.6 & 16.0 & 6.13 & 2.97 & 2.06 \\
\hline 1955 & 208.7 & -1.6 & -12.0 & 10.4 & 1.01 & 2.58 & 0.39 \\
\hline 1956 & 269.0 & 60.3 & 14.4 & 45.9 & 4.69 & 2.96 & 1.58 \\
\hline 1957 & 377.9 & 108.9 & 21.9 & 87.0 & 7.40 & 3.68 & 2.01 \\
\hline 1958 & 342.9 & -35.0 & -21.5 & -13.5 & -2.82 & 3.19 & -0.88 \\
\hline 1959 & 447.5 & 104.6 & -3.8 & 108.4 & 6.41 & 3.60 & 1.78 \\
\hline 1960 & 619.6 & 172.1 & 0.0 & 172.1 & 7.33 & 4.19 & 1.75 \\
\hline 1961 & 777.3 & 157.7 & -39.9 & 197.6 & 5.91 & 4.29 & 1.38 \\
\hline 1962 & 866.6 & 89.3 & -1.3 & 90.6 & 5.26 & 4.37 & 1.20 \\
\hline 1963 & 931.5 & 64.9 & 12.8 & 52.1 & 1.42 & 3.96 & 0.36 \\
\hline 1964 & $1,064.1$ & 132.6 & -58.6 & 191.2 & 5.19 & 3.91 & 1.33 \\
\hline 1965 & $1,082.1$ & 18.0 & -56.6 & 74.6 & 2.52 & 3.59 & 0.70 \\
\hline 1966 & $1,195.9$ & 113.8 & -98.7 & 212.5 & 4.16 & 3.39 & 1.23 \\
\hline 1967 & $1,550.0$ & 354.1 & -30.3 & 384.4 & 6.32 & 3.75 & 1.69 \\
\hline
\end{tabular}

Source: Economic Planning Agency, Revised Report on National Income Statistics (1951-67) and estimates of discretionary tax classes furnished by the Ministry of Finance. 


\section{REFERENCES}

[1] Brown, E. CARY, "Fiscal Policy in the Thirties: A Reappraisal," American Economic Review, XXXXVI (December, 1956), 857-879.

[2] HANSEN, BeNt, "Statsbudgetens verkningar," Ekonomisk Tidskrift, LXI (1959, 3), 128.

[3] , assisted by Wayne W. Snyder, Fiscal Policy in Seven Countries, 1955-65 (Paris: Organization for Economic Cooperation and Development, 1969).

[ 4 ] Ishi, HIRomitsu, "The Income Elasticity of the Tax Yield in Japan," Hitotsubashi Journal of Economics, IX (June, 1968), 45-63.

[5] Karzuka, K., "The Stabilization Effect of Fiscal Policy," in K. Komiya ed., Postwar Economic Growth in Japan (Berkeley: University of California Press, 1966).

[6] Kirschen, E. S., et al., Economic Policy in Our Time (Amsterdam: North-Holland Publishing Company, 1964).

[7] LINDBECK, ASSAR, "Statsbudgetens verkningar pa konjunturuveckliagen," Statens Offentliga Utredningar (1956, 48).

[8] LUndberg, ERIK, Instability and Economic Growth (New Haven: Yale University Press, 1968).

[9] MADDISON, ANGUS, Economic Growth in Japan and the USSR (New York: W. W. Norton and Company, 1969).

[10] Musgrave, Richard A., "On Measuring Fiscal Performance," Review of Economics and Statistics, LXVI (May, 1964), 213-220.

[11] Tatemoto, Masahiro, Tadao Uchida, and Tsunehiko Watanabe, "A Stabilization Model for the Postwar Japanese Economy: 1954-62," International Economic Review, VIII (February, 1967), 13-44.

[12] Japan Economic Planning Agency, Economic and Social Plan (Tokyo: 1970).

[13] _ Revised Report on National Income Statistics 1951-67 (Tokyo: August, 1969).

[14] Short-term Economic Forecasting Model (Tokyo: 1970).

[15] White Paper on the Japanese Economy, 1969 (Tokyo: 1970).

[16] Institute of Economic Research, Keizai Bunseki.

[17] Organization for Economic Co-Operation and Development, Development Plans and Programmes (Paris: O.E.C.D., 1964), Saburo Okita and Isamu Miyazaki, "The Impact of Planning on Economic Growth in Japan," 41-66.

[18] Organization for Economic Co-operation and Development, Economic Surveys, Japan (Paris: O.E.C.D., December, 1965).

[19] United States, Council of Economic Advisors, Economic Report of the President (Washington, D. C.: U.S. Government Printing Office, January, 1962). 


\section{CRED Reprint Series}

*No. 15. "Some Implications of Postwar Primary-Product Trends" by Richard C. Porter. (The Journal of Political Economy, Vol. 78, No. 3, May-June 1970, pp. 586-597)

No. 16. "Measuring the Effects of German Budget Policies, 1955-65" by Wayne W. Snyder. (Weltwirtschaftliches Archiv, Vol. 104, No. 2, 1970, pp. 302-324)

No. 17. "Politics, Privilege and Progress in Liberia-A Review Article" by Elliot J. Berg. (Liberian Studies Journal, Vol. II, No. 2, 1970, pp. 175-183)

*No. 18. "Terminal-Year Investment in Finite-Horizon Planning Models" by Richard C. Porter. (Pakistan Development Review, Summer, 1970, pp. 272-280)

*No. 19. "Measuring the Stabilizing Effects of Social Security Programs in 7 Countries, 1955-65" by Wayne W. Snyder. (National Tax Journal, September 1970, pp. 263-273)

No. 20. "Measuring Economic Stabilization: 1955-65" by Wayne W. Snyder. (The American Economic Review, December 1970, pp. 924-933)

*No. 21. "Further Comment on the Kilby/Weeks Debate: An Empirical Rejoinder" by John F. Weeks. (The Journal of Developing Areas, January 1971, pp. 165-174)

No. 22. "Structural Transformation versus Gradualism: Recent Economic Development in Ghana and the Ivory Coast" by Elliot J. Berg. (Ghana and the Ivory Coast: Perspectives of Modernization, edited by Philip Foster and Aristide R. Zolberg. Published by University of Chicago Press, 1971, pp. 187-230)

No. 23. "Budget, Economic Policy, and Economic Performance in Underdeveloped Countries" by Wolfgang F. Stolper. (Kieler Vorträge, Neue Folge 69, 1971, 33 pp.)

No. 24. "Limitations of Comprehensive Planning in the Face of Comprehensive Uncertainty: Crisis of Planning or Crisis of Planners?" by Wolfgang F. Stolper. (Weltwirtschaftliches Archiv, Vol. 107, No. 1, 1971, pp. 1-32)

*No. 25. "Managing Money and Credit in a Developing Economy" by Wayne W. Snyder. (Malayan Economic Review, Vol. XVI, No. 1, April 1971, pp. 1-12)

*No. 26. "The Control of Annual Plans: The Experience of Tunisia" by J. G. Kleve. (Journal of Modern Africa Studies, Cambridge University Press, Vol. 9, No. 2, August 1971, pp. 306-310)

No. 27. "The Rediscovery of Exports by the Third World" by Richard C. Porter and Charles P. Staelin. (Foreign Trade Review, January-March 1972, pp. 523-539)

No. 28. "Budget Policy and Economic Stability in Postwar Japan" by Wayne Snyder and Tsutomu Tanaka. (International Economic Review, Vol. 13, No. 1, February 1972, pp. 85-110) 
